\title{
Phylogenetic and protein prediction analysis reveals the taxonomically diverse distribution of virulence factors in the Bacillus cereus group
}

Ming Zhang ${ }^{1}$, Jun Liu ${ }^{1}$, Zhenzhen Yin ${ }^{1 *}$, Li Zhang ${ }^{2 *}$

${ }^{1}$ School of Yunkang Medicine and Health, Nanfang College, Guangzhou, Guangdong, China;

${ }^{2}$ School of Life Science, Liaoning University, Shenyang, Liaoning, China.

* Corresponding author

E-mail: 837949196@qq.com (ZY); fmtzhangli@qq.com (LZ)

Bacillus cereus is a food contaminant with widely varying enterotoxic potential of its virulence proteins. In

this article, phylogenetic analysis of the whole-genome amino acid sequences of 41 strains, evolutionary distance calculation of the amino acid sequences of the virulence genes, and functional and structural prediction of the virulence proteins were performed to reveal the taxonomically diverse distribution of virulence factors. The genome evolution of the strains showed a clustering trend based on the coding virulence genes. The strains of $B$. cereus have evolved into non-toxic risk and toxic risk clusters with medium-high- and medium-low-risk clusters. The distances of evolutionary transfer relative to housekeeping genes of incomplete virulence genes were greater than those of complete virulence genes, and the distance values of HblACD were higher than those of nheABC and CytK among the complete virulence genes. Cytoplasmic localization was impossible for all the virulence proteins, and NheB, 
Nhe trimers and Hbl trimers, respectively. The ‘cap' of CytK, which includes two 'latches' with many $\beta$-sheets,

formed a $\beta$-barrel structure with pores, and a 'rim' balanced the structure. The evolution of B. cereus strains showed

\section{Introduction}


43

encode $\mathrm{Nhe} A \mathrm{BC}$ can be detected in nearly all enteropathogenic $B$. cereus strains, $h b l B C D$ can be detected in approximately $45 \%$ to $65 \%$ of such strains, and $c y t K$ is less prevalent $[4,5]$. B. cereus species which were compared on the basis of $16 \mathrm{~S}$ rRNA (identity values $>98 \%$ ), were closely homologous to each other [6]. Some papers have reported that the species affiliation of B. cereus group strains, which could lead to an exchange of virulence plasmids between species, often does not match patterns of phylogenetic relatedness [7,8]. While the enterotoxins of B. cereus are chromosome-coded, the unique characteristics are observed for plasmids and are thus present throughout the B. cereus group [9]. Lapidus et al. (2008) reported a large plasmid with an operon encoding all three Nhe components in a B. cereus strain [10]. There is evidence that extensive gene exchange occurs between plasmids and the chromosome during the evolution of the B. cereus group [11]. Therefore, some genes encoded on plasmids can spread via horizontal gene transfer among $B$. cereus and the transfer of a single plasmid from one species to another [12]. Didelot et al. (2009) detected three phylogenetic groups (clades) in a study on the evolution of pathogenicity in the $B$. cereus group [13]. Later, seven major phylogenetic groups with ecological differences were identified in the B. cereus group [14]. A recent study suggested that nine phylogenetic clades of isolates may be better for assessing the risk of diarrheal foodborne disease caused by B. cereus group isolates [15]. These studies of virulence factors of B. cereus concern the evolutionary classification of virulence genes, and there have been few comparative analyses of the relative evolutionary distance of virulence genes and the prediction of virulence protein function and structure. In this study, the genome, virulence gene sequences and predicted virulence proteins of 41 B. cereus strains were comparatively analyzed. This work aims to examine the species diversity of the $B$. cereus group and the phylogenetic relationships among virulence factors, systematically 

of virulence proteins.

\section{Materials and methods}

\section{Characterization of $B$. cereus strains} annotation information of the stains were downloaded from the NCBI.

75

76

Table 1. The forty-one B. cereus strains and one control strain used in this study

\begin{tabular}{|c|c|c|c|c|c|c|c|c|c|}
\hline \multirow[t]{2}{*}{ Strain } & \multirow{2}{*}{$\begin{array}{l}\text { Length } \\
(\mathrm{Mb})\end{array}$} & \multirow{2}{*}{$\begin{array}{l}\mathrm{G}+\mathrm{C} \\
(\%)\end{array}$} & \multirow{2}{*}{$\begin{array}{c}\text { Completeness } \\
(\%)\end{array}$} & \multirow{2}{*}{$\begin{array}{c}\text { Contamination } \\
(\%)\end{array}$} & \multirow[t]{2}{*}{ Origin } & \multirow{2}{*}{$\begin{array}{l}\text { Enterotoxic } \\
\text { risk potential }\end{array}$} & \multicolumn{3}{|c|}{ Analysis of enterotoxic genes } \\
\hline & & & & & & & nheABC & hblaCD & $c y t K$ \\
\hline B4264 & 5.42 & 35.30 & 98.99 & 0.00 & Pneumonia & $\mathrm{H}$ & + & + & + \\
\hline ATCC14579 & 5.43 & 35.31 & 98.99 & 1.35 & Soil & $\mathrm{H}$ & + & + & + \\
\hline FORC_013 & 5.68 & 35.20 & 98.99 & 0.00 & Foodborne & $\mathrm{H}$ & + & + & + \\
\hline 03BB102 & 5.45 & 35.29 & 98.99 & 0.00 & Pneumonia & $\mathrm{L}$ & + & - & - \\
\hline ATCC10987 & 5.43 & 35.52 & 98.99 & 0.00 & Soil & M & + & - & + \\
\hline G9842 & 5.74 & 35.05 & 98.99 & 2.02 & Stool & M & + & + & - \\
\hline AH820 & 5.59 & 35.31 & 98.48 & 0.00 & Periodontitis & $\mathrm{H}$ & + & + & + \\
\hline F837/76 & 5.29 & 35.40 & 98.99 & 0.00 & Enteritis & M & + & + & - \\
\hline Q1 & 5.51 & 35.50 & 98.99 & 0.34 & $\mathrm{Nd}$ & - & $A B$ & - & - \\
\hline CI & 5.49 & 35.27 & 98.99 & 1.01 & Anthrax & $\mathrm{L}$ & + & - & - \\
\hline E33L & 5.84 & 35.17 & 98.99 & 0.00 & Carcass & M & + & - & + \\
\hline AH187 & 5.60 & 35.52 & 98.99 & 0.00 & $\mathrm{Nd}$ & - & $A B$ & - & - \\
\hline NC7401 & 5.55 & 35.54 & 98.99 & 0.00 & Soil & - & $A B$ & - & - \\
\hline SGAir0263 & 6.47 & 34.91 & 98.99 & 0.34 & Air & M & + & + & - \\
\hline SGAir0260 & 6.30 & 34.97 & 98.99 & 0.34 & Air & M & + & + & - \\
\hline
\end{tabular}




\begin{tabular}{|c|c|c|c|c|c|c|c|c|}
\hline BHU1 & 5.20 & 35.10 & 98.99 & 0.00 & Soil & $\mathrm{L}$ & - & + \\
\hline Col-1 & 6.38 & 35.10 & 98.99 & 0.00 & Wastewater & $\mathrm{L}$ & - & + \\
\hline ATCC 4342 & 5.23 & 35.20 & 98.99 & 0.34 & Food & M & + & + \\
\hline BDRD-Cer4 & 5.40 & 35.10 & 97.98 & 0.34 & Food & $\mathrm{H}$ & + & + \\
\hline $\mathrm{m} 1550$ & 5.25 & 35.10 & 98.99 & 0.00 & Food & $\mathrm{H}$ & + & + \\
\hline $95 / 8201$ & 5.58 & 35.10 & 98.99 & 1.01 & Endocarditis & M & + & - \\
\hline $172560 \mathrm{~W}$ & 5.70 & 34.80 & 98.99 & 0.00 & Human & M & + & $C D$ \\
\hline Rock3-29 & 5.88 & 34.90 & 98.99 & 0.00 & Soil & - & $A B$ & $C D$ \\
\hline Rock1-3 & 5.86 & 34.90 & 98.99 & 0.00 & Soil & - & $A B$ & $C D$ \\
\hline Rock4-18 & 5.92 & 35.00 & 98.99 & 0.00 & Soil & - & $A B$ & $C D$ \\
\hline Rock1-15 & 5.77 & 34.90 & 98.99 & 1.01 & Soil & $\mathrm{H}$ & + & + \\
\hline BDRD- & 5.44 & 35.10 & 98.99 & 0.00 & $\mathrm{Nd}$ & $\mathrm{H}$ & + & + \\
\hline ATCC10876 & 5.94 & 34.80 & 98.99 & 0.00 & $\mathrm{Nd}$ & $\mathrm{H}$ & + & + \\
\hline Rock4-2 & 5.77 & 34.90 & 89.81 & 0.34 & Soil & $\mathrm{H}$ & + & + \\
\hline BGSC6E1 & 5.73 & 35.00 & 98.99 & 0.00 & $\mathrm{Nd}$ & M & + & + \\
\hline F65185 & 6.13 & 34.70 & 97.98 & 0.34 & Wound & M & + & $A D$ \\
\hline Rock3-28 & 6.04 & 35.75 & 96.46 & 0.34 & Soil & - & $A B$ & $C D$ \\
\hline Rock3-42 & 5.20 & 35.20 & 98.99 & 0.00 & Soil & M & + & - \\
\hline $\mathrm{m} 1293$ & 5.27 & 35.35 & 98.99 & 0.34 & Food & - & $A B$ & - \\
\hline BDRD- & 5.58 & 35.20 & 98.99 & 0.34 & $\mathrm{Nd}$ & - & $A B$ & $C D$ \\
\hline AH676 & 5.59 & 35.00 & 98.99 & 1.01 & Soil & M & + & $A D$ \\
\hline AH1271 & 5.66 & 35.30 & 98.99 & 0.00 & Lamp & M & + & + \\
\hline AH1272 & 5.79 & 35.20 & 97.47 & 1.35 & Amniotic & L & + & $D$ \\
\hline AH1273 & 5.79 & 35.25 & 96.93 & 1.35 & Blood & $\mathrm{L}$ & + & $D$ \\
\hline R309803 & 5.59 & 35.30 & 98.99 & 0.00 & Clinic & L & + & - \\
\hline BDRD- & 5.57 & 35.25 & 98.99 & 0.00 & $\mathrm{Nd}$ & - & $A B$ & - \\
\hline Control-70- & 3.31 & 45.30 & 98.99 & 0.00 & $\mathrm{Nd}$ & - & - & - \\
\hline
\end{tabular}

77 Nd: not determined; Enterotoxic: relative toxicity determined by gene expression; + or -: all or none, respectively; H, M, or L:

78 three, two, or one type(s) of toxic genes, respectively. Enterotoxic risk potential: toxicity via the expression of the nheABC,

$79 \quad h b l A C D$, and $c y t K$ genes.

81 Quality assessment of genomic sequences

82 The contamination and completeness of the metagenomic sequences were evaluated by

83 CheckM software version v1.1.3 [16].

\section{Phylogenetic and average nucleotide identity (ANI) analysis}



constructs whole-genome-based phylogenetic trees without sequence alignment by using a composition vector $(\mathrm{CV})$ approach, and the K-tuple length was 6 [17]. Every genome sequence was version 3.695 [22].

\section{Multilocus sequence analysis (MLSA)}

A total of forty-one strains containing gene sequences, which were downloaded from the NCBI, 
the basic evolutionary distances of the species. These housekeeping genes, scattered across the

entire chromosome, are suitable for MLSA [23]. The types of enterotoxin genes ( $n h e, h b l$, and $c y t K$ )

Thus, rearrangement of genes was unnecessary because the order of the genes within the operons

\section{Prediction of virulence protein function and structure}


of the virulence proteins analyzed were submitted in FASTA format. To predict structure, we performed homology modeling to generate 3-D virulence protein structures.

\section{General genome characteristics and quality assessment of}

\section{sequences}

A summary of the features of the forty-one genomes of B. cereus and the control genome of the closely related species $T$. sporolactobacillus is provided in Table 1 . The genome sizes of B. cereus strains varied from 5.20 to $6.47 \mathrm{MB}$. The $\mathrm{G}+\mathrm{C}$ contents of the forty-one genomes ranged from $34.70 \%$ to $35.75 \%$. Compared with the control genome from T. sporolactobacillus, the genomes of B. cereus were much larger and had lower $\mathrm{G}+\mathrm{C}$ contents. The contamination and completeness of the sequences were $0-2.02 \%$ and $89.81 \%-98.99 \%$, respectively (shown in Table 1). The results suggested that these sequences are of high quality and have low contamination (values $<2.02 \%$ ) and high completeness (values $>89.81 \%$ ); thus, they were appropriate for analysis. In this study, the strains originated from food (5/41), the clinic (12/41), the environment (17/41), and undetermined sources (7/41). The enterotoxic risk potential based on the virulence genes of forty-one B. cereus strains is listed in Table 1. Enterotoxicity, which was reflected by virulence gene numbers, was categorized into levels of three types (10/41), two types (14/41), one type (7/41), and no types (10/41) levels. The genes detected as enterotoxic were nheABC (29/41), hblACD (19/41), cytk (18/41), nhe AB (10/41), hblCD (6/41), hblAD (2/41), and hblD (2/41).

\section{Phylogenetic analysis based on whole amino acid sequences}


phylogenetic tree was constructed with the CV method using the whole amino acid sequences of forty-

of the results, we added the inbuilt sequence AH1273 and the sequence of T. sporolactobacillus (control)

Fig. 1 Phylogenetic relationships of the amino acid sequences of forty-one $B$. cereus strains and one external control strain used in

potential. 
(15/17) but also included two low-risk strains (BHU1 and CO1-1), was the same as region I. Regions B and $\mathrm{D}_{1}$, which included only nonrisk strains $(9 / 9)$, were the same as regions II and III. Regions $\mathrm{C}, \mathrm{D}_{2}$ and

\section{housekeeping and virulence genes}

To analyze the evolution and phylogenetic relationships of virulence gene transfer in relation to average difference in the phylogenetic DV of the ATCC14579 strain compared with forty other strains. 


\section{Comparative prediction analysis of the function and}

\section{structure of virulence proteins}

As shown in Table 2, we obtained the scores of the seven virulence proteins for subcellular 
211 Table 2. Subcellular localization, transmembrane helix and region, signal peptide, and domain prediction results of the virulence proteins of $B$. cereus strains.

\begin{tabular}{|c|c|c|c|c|c|c|c|c|c|c|c|c|}
\hline \multirow{2}{*}{ Name } & \multirow{2}{*}{ Final localization } & \multirow{2}{*}{ Final score } & \multicolumn{4}{|c|}{ Scores for different localizations } & \multirow{2}{*}{$\begin{array}{l}\text { Helix } \\
\text { number }\end{array}$} & \multirow{2}{*}{$\begin{array}{c}\text { Transmembrane } \\
\text { region }\end{array}$} & \multirow{2}{*}{$\begin{array}{l}\text { Cleavage } \\
\text { site }\end{array}$} & \multirow{2}{*}{$\begin{array}{c}\text { Signal peptide } \\
\text { likelihood }\end{array}$} & \multirow{2}{*}{$\begin{array}{l}\text { Signal peptide } \\
\text { start-end }\end{array}$} & \multirow{2}{*}{$\begin{array}{l}\text { Domain } \\
\text { start-end }\end{array}$} \\
\hline & & & Cytoplasmic membrane & Cell wall & Extracellular & Cytoplasmic & & & & & & \\
\hline NheA & Unknown & $3.33 / 4.60$ & $3.33 / 4.60$ & $3.33 / 2.48$ & $3.33 / 2.92$ & 0.00 & 0 & - & 26 and 27 & $0.81 \pm 0.07$ & $1-26$ & $41-216$ \\
\hline NheB & Extracellular & 9.73 & 0.09 & 0.18 & 9.73 & 0.00 & 2 & 235-257;267-286 & 30 and 31 & $0.99 \pm 0.01$ & $1-30$ & $54-232$ \\
\hline NheC & Extracellular & 9.73 & 0.09 & 0.18 & 9.73 & 0.00 & 1 & $228-250$ & 30 and 31 & $0.98 \pm 0.02$ & $1-23$ & $46-224$ \\
\hline Hbl-B & Extracellular & 9.73 & 0.09 & 0.18 & $9.73 / 9.72$ & 0.00 & 0 & - & 31 and 32 & $0.96 \pm 0.04$ & - & $45-224$ \\
\hline $\mathrm{Hbl}-\mathrm{L}_{1}$ & Extracellular & 9.73 & 0.09 & 0.18 & 9.73 & 0.00 & 2 & 239-261;268-290 & 30 and 31 & $0.98 \pm 0.01$ & $1-20$ & $44-230$ \\
\hline $\mathrm{Hbl}-\mathrm{L}_{2}$ & Unknown & $3.33 / 4.60$ & $3.33 / 4.60$ & $3.33 / 2.48$ & $3.33 / 2.92$ & 0.00 & 0 & - & 32 and 33 & $0.93 \pm 0.05$ & - & $35-207$ \\
\hline CytK & Extracellular & 9.98 & 0.00 & 0.02 & 9.98 & 0.00 & 0 & - & 31 and 32 & $0.99 \pm 0.01$ & $1-31$ & 64-329 \\
\hline
\end{tabular}


Fig. 4 The locations of transmembrane helices, cleavage sites, signal peptides, and domain start-ends were predicted by TMHMM,

$\mathrm{B}$, and $\mathrm{Hbl}-\mathrm{L}_{1}$ were included in the SWISS-MODEL server with high sequence identity $(97.22 \%, 71.99 \%$, 


\begin{tabular}{|c|c|c|c|c|c|c|c|c|}
\hline Name & $\begin{array}{c}\text { Template } \\
\text { number }\end{array}$ & $\begin{array}{l}\text { Template } \\
\text { description }\end{array}$ & $\begin{array}{c}\text { Sequence } \\
\text { identity }\end{array}$ & $\begin{array}{l}\text { Sequence } \\
\text { coverage }\end{array}$ & $\begin{array}{c}\text { Sequence } \\
\text { range }\end{array}$ & GMQE & $\begin{array}{c}\text { AlphaFold } \\
\text { plDDt }\end{array}$ & $\begin{array}{l}\text { AlphaFold } \\
\text { ipTM+pTM }\end{array}$ \\
\hline NheA & 4k1p.1.A & NheA & $97.22 \%$ & 0.93 & $42-386$ & 0.88 & 93.86 & - \\
\hline NheB & 7nmq.1.A & Hbl- $\mathrm{L}_{1}$ & $40.82 \%$ & 0.85 & $52-397$ & 0.69 & 83.42 & - \\
\hline NheC & 7nmq.1.A & Hbl- $\mathrm{L}_{1}$ & $36.83 \%$ & 0.88 & $44-358$ & 0.68 & 90.25 & - \\
\hline Hbl-B & 2nrj.1.A & Hbl-B & $71.99 \%$ & 0.71 & $33-364$ & 0.61 & 91.73 & - \\
\hline Hbl- $\mathrm{L}_{1}$ & 7nmq.1.A & Hbl- $\mathrm{L}_{1}$ & $99.73 \%$ & 0.90 & $41-405$ & 0.88 & 81.90 & - \\
\hline $\mathrm{Hbl}-\mathrm{L}_{2}$ & 4k1p.1.A & NheA & $24.85 \%$ & 0.74 & $38-439$ & 0.54 & 94.14 & - \\
\hline CytK & 3yhd.1.A & Alpha-hemolysin & $30.39 \%$ & 0.84 & $35-334$ & 0.61 & 89.75 & - \\
\hline Nhe-trimer & - & - & - & - & - & - & - & 0.68 \\
\hline Hbl-trimer & - & - & - & - & - & - & - & 0.36 \\
\hline
\end{tabular}

The global model quality estimate (GMQE) is a quality estimate that combines properties from the target-template alignment and

Fig. 5 The phylogenetic tree of Hbl-B, Hbl- $\mathrm{L}_{1}, \mathrm{Hbl}-\mathrm{L}_{2}$, NheA, NheB, NheC, and CytK component sequences with the ATCC14579 strain.

Due to the sequence similarity of NheB and NheC with Hbl-B, homology models based on the Hblmany $\beta$-sheets of CytK folded the 'cap' domain, which was the toxic area (Figs 6e and 7G). The amino 

formation of trimers.

Fig. 7 Overview of the structure predicted by AlphaFold software. A, B, C, D, E, and F are the structures of NheA, NheB, NheC,

Hbl-B, Hbl- $\mathrm{L}_{1}$, and Hbl- $\mathrm{L}_{2}$, which are annotated with the 'head' and 'tail', respectively. A and $D$ show beta-tongues in the 'head'

\section{Discussion}


and the regional distribution of the number of types of virulence genes was also presented, further confirmed by ANI-based phylogenetic analyses. We found that the two phylogenetic trees were similar.

278 All non-toxic-risk strains were concentrated in two clusters, and all but two of the medium-high- and

279 medium-low-toxic-risk strains formed clusters. The results suggest the possibility of virulence gene transfer, which may be related to frequent exchange of pathogenicity factors during B. cereus virulence evolution, including so-called probiotic or nonpathogenic species [12]. The inconsistent evolutionary distribution of individual virulence genes may be due to other factors, which needs further study. enterotoxins produced by B. cereus. Cardazzo et al. (2008) detected horizontal gene transfer in the evolution of enterotoxins within the B. cereus group [39]. Our MLSA results showed that in the process of toxin molecular evolution, two toxic-type genes had a more significant effect in relation to DVs than three toxic-type genes. The results suggested that the complete virulence-gene operon combination has higher relative genetic stability. The DV of hemolysin Bl was greater than that of nonhemolytic cytotoxin

291 K. nhe $A B C$, which was responsible for most of the cytotoxic activity of $B$. cereus isolates, showed stable, relative genetic stability [12]. 
two lytic components $B, C$ and $-L_{1},-L_{2}$, with all three subunits acting synergically to cause illness. The component and $\mathrm{Hbl} \mathrm{B}$ had none, which may strengthen the secretion of the Nhe protein.

315 NheB, NheC, HBl-B, HBl- $\mathrm{L}_{1}$, and HBl- $\mathrm{L}_{2}$ structures showed two main domains, a 'head' and 'tail'. The

316 'heads' of NheA and Hbl-B, including two $\alpha$-helices separated by $\beta$-tongue strands, play a special role

317 in Nhe trimers and $\mathrm{Hbl}$ trimers, respectively. Upon contact with lipids, cell membranes or detergents, the 
NheC, Hbl- $\mathrm{L}_{1}$, and Hbl- $\mathrm{L}_{2}$ had few or no $\beta$-strands in the 'head', which were either responsible for conformational changes of NheA and Hbl-B or for the stabilization of the 'head' domain [46] or might

322 lead to reduced toxicity or only ligand function [37]. The difference was reflected in the triplet prediction results, i.e., a significant difference in structural arrangement compactness between Nhe trimers (noncompact type) and $\mathrm{Hbl}$ trimers (compact type). Ganash et al. (2013) speculated that the Nhe trimer requires interaction with unknown proteins of an additional function [37]. A specific binding order of the three Nhe and $\mathrm{Hbl}$ components is also necessary for pore formation $[51,52]$. We found that NheB and $\mathrm{Hbl}-\mathrm{L}_{1}$ were close to NheA and Hbl-B in the predicted trimer structure. Didier et al. (2016) found that NheA is important for attaching to cell-bound NheB and NheC and that NheB is the main interaction partner of NheA [53], and a further correlation was found for the amounts of $\mathrm{Hbl} \mathrm{B}$ and $\mathrm{Hbl} \mathrm{L}_{1}$ [42]. region, which was folded into a three-stranded antiparallel $\beta$-sheet, balanced the structure in the monomer.

334 The predicted structure revealed that CytK was likely to belong to the leukocyte toxin family. These

\section{Conclusion}


341 stability than the incomplete operon. The two $\alpha$-helices in the 'head' of the NheA and Hbl-B structures,

343 of the CytK structure might play a special role in the binding of virulence structures and pore-forming

344 toxins in B. cereus. Overall, the exact mechanism by which B. cereus causes diarrhea remains unknown,

345 but our results provide helpful information for better understanding the taxonomically diverse

346 distribution of virulence factors in the B. cereus group.

\section{Abbreviations}

348 ANI average nucleotide identity

349 MLSA multilocus sequence analysis

350 Nhe nonhemolytic enterotoxin

$351 \mathrm{Hbl}$ hemolysin BL

CytK cytotoxin $\mathrm{K}$

353 DV distance value

354 CV composition vector

355 GMQE global model quality estimate

356 NCBI National Center for Biotechnology Information

$357 \quad a d k \quad$ adenylate kinase

$358 \quad$ cсpA catabolite control protein A

$359 \quad g l p F \quad$ glycerol uptake facilitator protein

$360 \quad$ glpT glycerol-3-phosphate transporter

361 panC pantoate-beta-alanine ligase 


\section{Author Contributions}

Formal analysis: Jun Liu

Resources: Ming Zhang

\section{References}

1. Webb MD, Barker GC, Goodburn KE, Peck MW. Risk presented to minimally processed chilled foods by psychrotrophic Bacillus cereus. Trends Food Sci Technol. 2019; 93(9): 94-105. doi: 10.1016/j.tifs.2019.08.024.

3. Rajkovic A, Jovanovic J, Monteiro S, Decleer M, Andjelkovic M, Foubert A, et al. Detection of toxins involved in foodborne diseases caused by Gram-positive bacteria. Compr Rev Food Sci Food Saf. 2020; 19(4):1605-1657. doi: 10.1111/1541-4337. 12571.

4. Jessberger N, Dietrich R, Schwemmer S, Tausch F, Schwenk V, Didier A, et al. Binding to the target cell surface is the crucial step in pore formation of hemolysin BL from Bacillus cereus. Toxins. 2019; 11(5): 281. doi: 10.3390/toxins11050281.

5. Koné KM, Douamba Z, Halleux M, Bougoudogo F, Mahillon J. Prevalence and diversity of the thermotolerant bacterium Bacillus cytotoxicus among dried food products. J Food Protec. 2019; 82(7): 1210-1216. doi: 10.4315/0362-028X.JFP-19-006

6. Thompson CC, Chimetto L, Edwards RA, Swings J, Stackebrandt E, Thompson FL. Microbial genomic taxonomy. BMC Genomics. 2013; 14: 913. doi: 10.1186/1471-2164-14-913.

7. Guinebretiere M, Thompson FL, Sorokin A, Normand P, Dawyndt P, Ehling- Schulz M, et al. Ecological diversification in the Bacillus cereus Group. Environ Microbiol. 2008; 10(4): 851-865. doi: 10.1111/j.1462-2920.2007.01495.x.

8. Helgason E, Okstad OA, Caugant DA, Johansen HA, Fouet A, Mock M, et al. Bacillus anthracis, Bacillus cereus, and Bacillus thuringiensis one species on the basis of genetic evidence. Appl Environ Microbiol. 2000; 66(6): 2627-2630. doi: 10.1128/ AEM.66.6.2627-2630.2000.

9. Dietrich R, Jessberger N, Ehling-Schulz M, Märtlbauer E, Granum PE. The Food Poisoning Toxins of Bacillus cereus. Toxins. 
2021; 13(2): 98. doi: 10.3390/TOXINS13020098.

10. Lapidus A, Goltsman E, Auger S, Galleron N, Ségurens B, Dossat C, et al. Extending the Bacillus cereus group genomics to putative food-borne pathogens of different toxicity. Chem. Interact. 2008; 171: 236-249. doi: 10.1016/j.cbi.2007.03.003.

11. Zheng J, Guan Z, Cao S, Peng D, Ruan L, Jiang D, Sun M. Plasmids are vectors for redundant chromosomal genes in the Bacillus cereus group. BMC Genom. 2015; 16(1): 6. doi: 10.1186/s12864-014-1206-5.

12. Böhm ME, Huptas C, Krey VM, Scherer S. Massive horizontal gene transfer, strictly vertical inheritance and ancient duplications differentially shape the evolution of Bacillus cereus enterotoxin operons hbl, cytK and nhe. BMC Evol Biol. 2015; 15(1): 246. doi: 10.1186/s12862-015-0529-4.

13. Didelot X, Barker M, Falush D, Priest FG. Evolution of pathogenicity in the Bacillus cereus group. Syst Appl Microbiol. 2009; 32(2): 81-90. doi: 10.1016/j.syapm.2009.01.001.

14. Guinebretière MH, Thompson FL, Sorokin A, Normand P, Dawyndt P, Ehling-Schulz M, et al. Ecological diversification in the Bacillus cereus group. Environ. Microbiol. 2008; 10(4): 851-865. doi: 10.1111/j.1462-2920.2007.01495.x.

15. Kovac J, Miller RA, Carroll LM, Kent DJ, Jian JH, Beno SM, et al. Production of hemolysin BL by Bacillus cereus group isolates of dairy origin is associated with whole-genome phylogenetic clade. BMC genomics. 2016; 17(1): 581. doi: 10.1186/ s12864-016-2883-z.

16. Parks DH, Imelfort M, Skennerton CT, Hugenholtz P. CheckM: assessing the quality of microbial genomes recovered from isolates, single cells, and metagenomes. Genome Res. 2015; 25:1043-1055. doi: 10.1101/gr.186072.114.

17. Zuo G, Hao B. CVTree3 web server for whole-genome-based and alignment-free prokaryotic phylogeny and taxonomy. Genom Proteom Bioinf. 2015; 13:321-331. doi: 10.1016/j.gpb.2015.08.004.

18. Zuo G. CVTree: A Parallel Alignment-free Phylogeny and Taxonomy Tool based on Composition Vectors of Genomes. Genom Proteom Bioinf. 2021. doi: 10.1016/j.gpb.2021.03.006.

19. Kumar S, Stecher G, Li M, Knyaz C, Tamura K. MEGA X: molecular evolutionary genetics analysis across computing platforms. Mol Biol Evol. 2018; 35(6): 1547. doi: 10.1093/molbev/msy096.

20. Richter M, Rosselló-Móra R, Glöckner FO, Peplies J. JSpeciesWS: a web server for prokaryotic species circumscription based on pairwise genome comparison. Bioinformatics. 2015; 32(6): 929-931. doi: 10.1093/bioinformatics/ btv681.

21. Perrière G, Gouy M. WWW-query: an on-line retrieval system for biological sequence banks. Biochimie. 1996; 78: 364-369. doi: 10.1016/0300-9084(96)84768-7

22. Baum Bernard R. PHYLIP: Phylogeny Inference Package. Version 3.2. Joel Felsenstein. Biology. 1989; 64(4): 539-541. doi:10.1086/416571

23. Tourasse NJ, Helgason E, Okstad OA, Hegna IK, Kolsto AB. The Bacillus cereus group: novel aspects of population structure and genome dynamics. J Appl Microbiol. 2006; 101(3): 579-593. doi: 10.1111/j.1365-2672.2006.03087.x.

24. Tamura K, Stecher G, Peterson D, Filipski A, Kumar S. MEGA6: Molecular Evolutionary Genetics Analysis version 6.0. Mol Biol Evol. 2013; 30(12): 2725-2729. doi: 10.1093/molbev/mst197.

25. Letunic I, Khedkar S, Bork P. SMART: recent updates, new developments and status in 2020. Nucleic Acids Res. 2020; 49(1): 458-460. doi: 10.1093/NAR/GKAA937.

26. Peabody MA, Laird MR, Vlasschaert C, Lo R, Brinkman FS. PSORTdb: expanding the bacteria and archaea protein subcellular localization database to better reflect diversity in cell envelope structures. Nucleic Acids Research. 2016; 44(D1): D663-668. doi: $10.1093 /$ nar/gkv1271.

27. Moller S, Croning MDR, Apweiler R. Evaluation of methods for the prediction of membrane spanning regions. Bioinformatics. 2001; 17(7): 646-653. doi: 10.1093/bioinformatics/17.7.646.

28. Almagro Armenteros JJ, Tsirigos KD, Sønderby CK, Petersen TN, Winther O, Brunak S, et al. SignalP 5.0 improves signal peptide predictions using deep neural networks. Nat Biotechnol. 2019; 37(4): 420-423. doi: 10.1038/s41587-019-0036-Z.

29. Biasini M, Bienert S, Waterhouse A, Arnold K, Studer G, Schmidt T, et al. SWISS-MODEL: modelling protein tertiary and quaternary structure using evolutionary information. Nucleic Acids Res. 2014; 42: 252-258. doi: 10.1093/nar/gku340. 
30. Jumper J, Evans R, Pritzel A, Green T, Flgurnov M, Ronneberger O, et al. Highly accurate protein structure prediction with AlphaFold. Nature. 2021; 596:583-589. doi: 10.1038/S41586-021-03819-2.

31. Evans R, O’Neill M, Pritzel A, Antropova N, Senior A, Green T, et al. Protein complex prediction with AlphaFold-Multimer. bioRxiv preprint. 2021 October 4. doi: 10.1101/2021.10.04.463034.

32. Thitiprasert S, Piluk J, Tolieng V, Tanaka N, Shiwa Y, Fujita N, et al. Draft genome sequencing of Sporolactobacillus terrae SBT-1, an efficient bacterium to ferment concentrated sugar to d-lactic acid. Arch Microbiol. 2021; 203(6): 1-14. doi: 10.1007/S00203-021-02352-0.

33. Sugawara T, Yamashita D, Kato K, Zhao P, Min Y. Structural basis for pore-forming mechanism of staphylococcal $\alpha$-hemolysin Toxicon. 2015; 108: 226-231. doi: 10.1016/j.toxicon.2015.09.033.

34. Sharma A, Ponmariappan S, Sariti R, Alam SI, kamboj DV, Shukla S. Identification of cross reactive antigens of C. botulinum types A, B, E \& F by immunoproteomic approach. Curr microbiol. 2018; 75(5): 531-540. doi: 10.1007/s00284-017-1413-9.

35. Mariani V, Biasini M, Barbato A, Schwede T. IDDT: a local superposition-free score for comparing protein structures and models using distance difference tests. Bioinformatics. 2013; 29: 2722-2728. doi: 10.1093/bioinformatics/btt473.

36. Takaki S, Daichi Y, Koji K, Zhao P, Junki U, Jun K, et al. Structural basis for pore-forming mechanism of staphylococcal $\alpha$ hemolysin. Toxicon. 2015; 108: 226-231. doi: 10.1016/j.toxicon.2015.09.033.

37. Ganash M, Phung D, Sedelnikova SE, Lindbäck T, Granum P, Artymiuk PJ. Structure of the NheA component of the Nhe toxin from Bacillus cereus: Implications for function. PLoS ONE. 2013; 8(9): e747-748. doi: 10.1371/journal.pone.0074748.

38. Phelps RJ, McKillip JL. Enterotoxin production in natural isolates of Bacillaceae outside the Bacillus cereus group. Appl Environ Microbiol. 2002; 68(6): 3147-3151. doi: 10.1128/AEM.68.6.3147-3151.2002.

39. Cardazzo B, Negrisolo E, Carraro L, Alberghini L, Patarnello T, Giaccone V. Multiple-locus sequence typing and analysis oftoxin genes in Bacillus cereus food-borne isolates. Appl Environ Microbiol. 2008; 74: 850-860. doi: 10.1128/AEM.01495-

40. Moravek M, Dietrich R, Buerk C, Broussolle V, Guinebretiere MH, Granum PE, et al. Determination of the toxic potential of Bacillus cereus isolates by quantitative enterotoxin analyses. FEMS Microbiol Lett. 2006; 257(2): 293-298. doi: 10.1111/j.15746968.2006.00185.x.

41. Dietrich R, Moravek M, Bürk C, Granum PE, Märtlbauer E. Production and characterization of antibodies against each of the three subunits of the Bacillus cereus nonhemolytic enterotoxin complex. Appl Environ Microbiol. 2005; 71(12): 8214-8220. doi: 10.1128/aem.71.12.8214-8220.2005.

42. Jessberger, N, Dietrich R, Bock S, Didier A, Märtlbauer E. Bacillus cereus enterotoxins act as major virulence factors and exhibitdistinct cytotoxicity to different human cell lines. Toxicon. 2014; 77(1): 49-57. doi: 10.1016/j.toxicon.2013.10.028.

43. Jessberger N, Krey VM, Rademacher C, Böhm ME, Mohr AK, Ehling-Schulz M, et al. From genometo toxicity: A combinatory approach highlights the complexity of enterotoxin production in Bacillus cereus. Front. Microbiol. 2015; 6(6): 560. doi: $10.3389 /$ fmicb.2015.00560.

44. Dietrich R, Jessberger N, Ehling-Schulz M, Märtlbauer E, Granum PE. The Food Poisoning Toxins of Bacillus cereus. Toxins. 2021; 13(2): 98-156. doi: 10.3390/toxins 13020098 .

45. Fagerlund A, Lindback T, Storset AK, Granum PE, Hardy SP. Bacillus cereus Nhe is a pore-forming toxin with structural and functional properties similar to the ClyA (HlyE, SheA) family of haemolysins, able to induce osmotic lysis in epithelia. Microbiol. 2008; 154 (Pt 3): 693-704. doi: 10.1099/mic.0.2007/014134-0.

46. Madegowda M, Eswaramoorthy S, Burley SK, Swaminathan S. X-ray crystal structure of the B component of Hemolysin BL from Bacillus cereus. Proteins Struct. Funct Bioinform. 2008: 71(2): 534-540. doi: 10.1002/prot.21888.

47. Phung D, Ganash M, Sedelnikova SE, Lindbäck T, Granum PE, Artymiuk PJ. Crystallization and preliminary crystallographic analysis of the NheA component of the Nhe toxin from Bacillus cereus. Acta Crystallographica. 2012; 68 (Pt 9): $1073-1076$. doi: $10.1107 / \mathrm{S} 1744309112030813$ 
48. Wallace AJ, Stillman TJ, Atkins A, Jamieson SJ, Bullough PA, Green J, et al. E. coli Hemolysin E (HlyE, ClyA, SheA). Cell. 2000; 100 (2): 265-276. doi: 10.1016/s0092-8674(00)81564-0.

49. Eifler N, Vetsch M, Gregorini M, Ringler P, Chami M, Philippsen A, et al. Cytotoxin ClyA from Escherichia coli assembles to a 13-meric pore independent of its redox-state. EMBO J. 2006; 25 (11): 2652-2661. doi: 10.1038/sj.emboj.7601130.

50. Mueller M, Grauschopf U, Maier T, Glockshuber R, Ban N. The structure of a cytolytic $\alpha$-helical toxin pore reveals its assembly mechanism. Nat Cell Biol. 2009: 459: 726-730. doi: 10.1038/nature08026.

51. Worthy HL, Williamson LJ, Auhim HS, Leppla SH, Sastalla I, Jones DD, et al. The crystal structure of Bacillus cereus HblL . Toxins. 2021; 13(4): 253-266. doi: 10.3390/toxins13040253.

52. Lindbäck T, Fagerlund A, Rødland MS, Granum PE. Characterization of the Bacillus cereus Nhe enterotoxin. Microbi. 2004; 150(Pt 12): 3959-3967. doi: 10.1099/mic.0.27359-0.

53. Didier A, Dietrich R, Märtlbauer E. Antibody binding studies reveal conformational flexibility of the Bacillus cereus nonhemolytic enterotoxin (Nhe) A-component. PLoS ONE. 2016; 11(10): e0165135. doi: 10.1371/journal.pone.0165135. 101(11): 2679-2683. doi: 10.1016/j.bpj.2011.09.054. keratinocyte and fibroblast cultures. J Dermatol Sci. 2005; 40(2): 141-143. doi: 10.1016/j.jdermsci.2005.08.005 

- Cotrol 


\section{Distance}

$$
\begin{array}{r}
0.016 \\
0.014 \\
0.012 \\
0.01 \\
0.008 \\
0.006 \\
0.004 \\
0.002 \\
0
\end{array}
$$
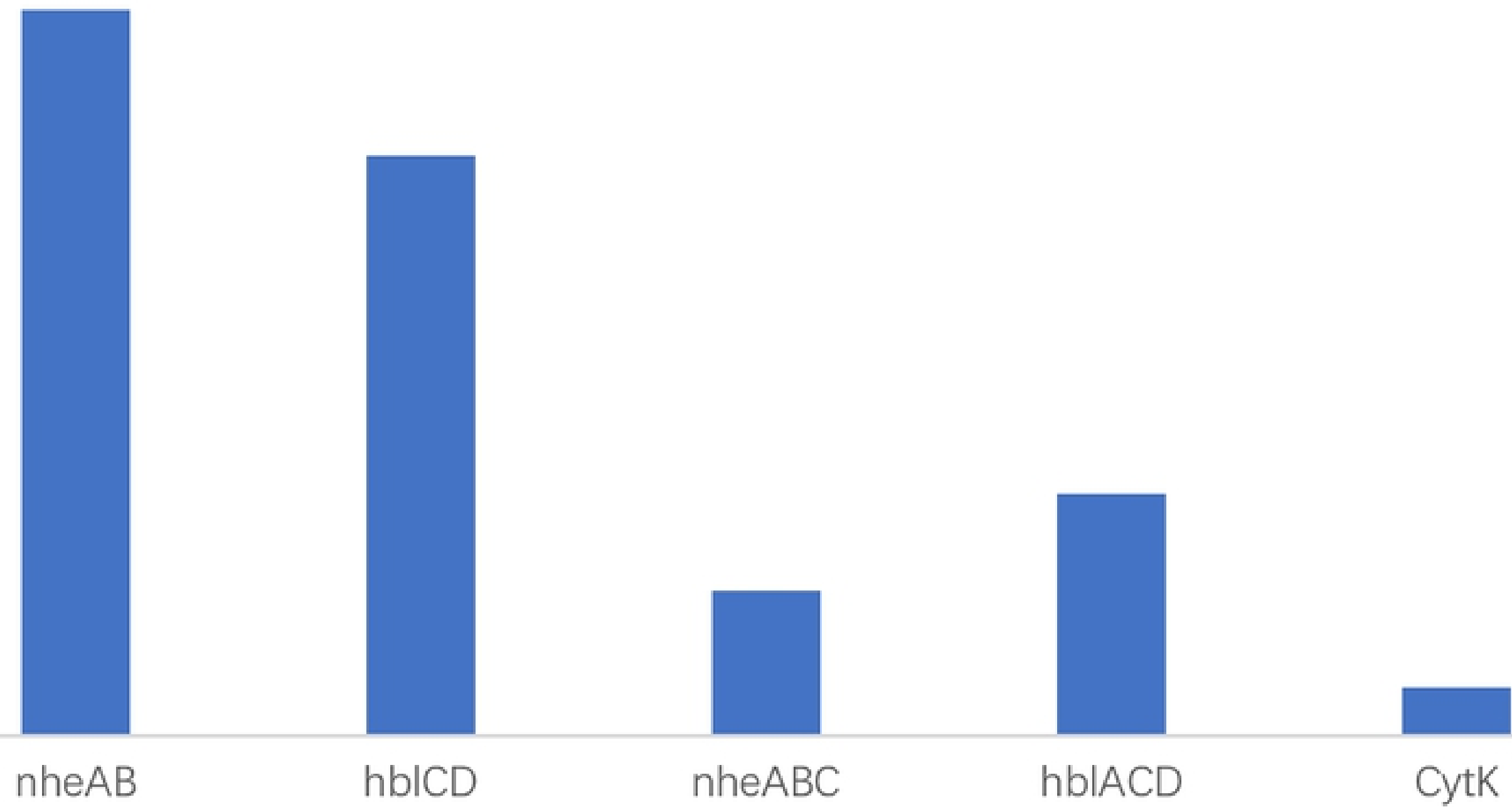

\section{Figure}



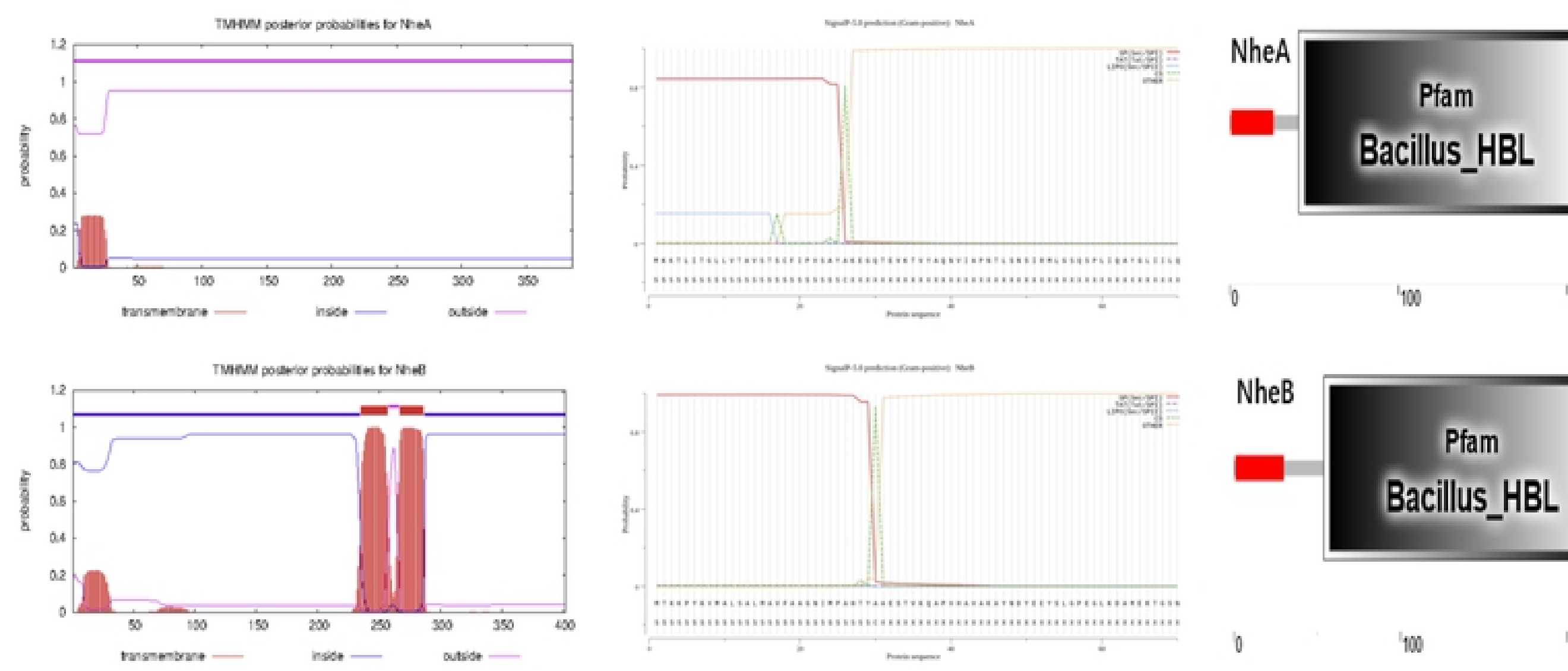

0

100

200

130
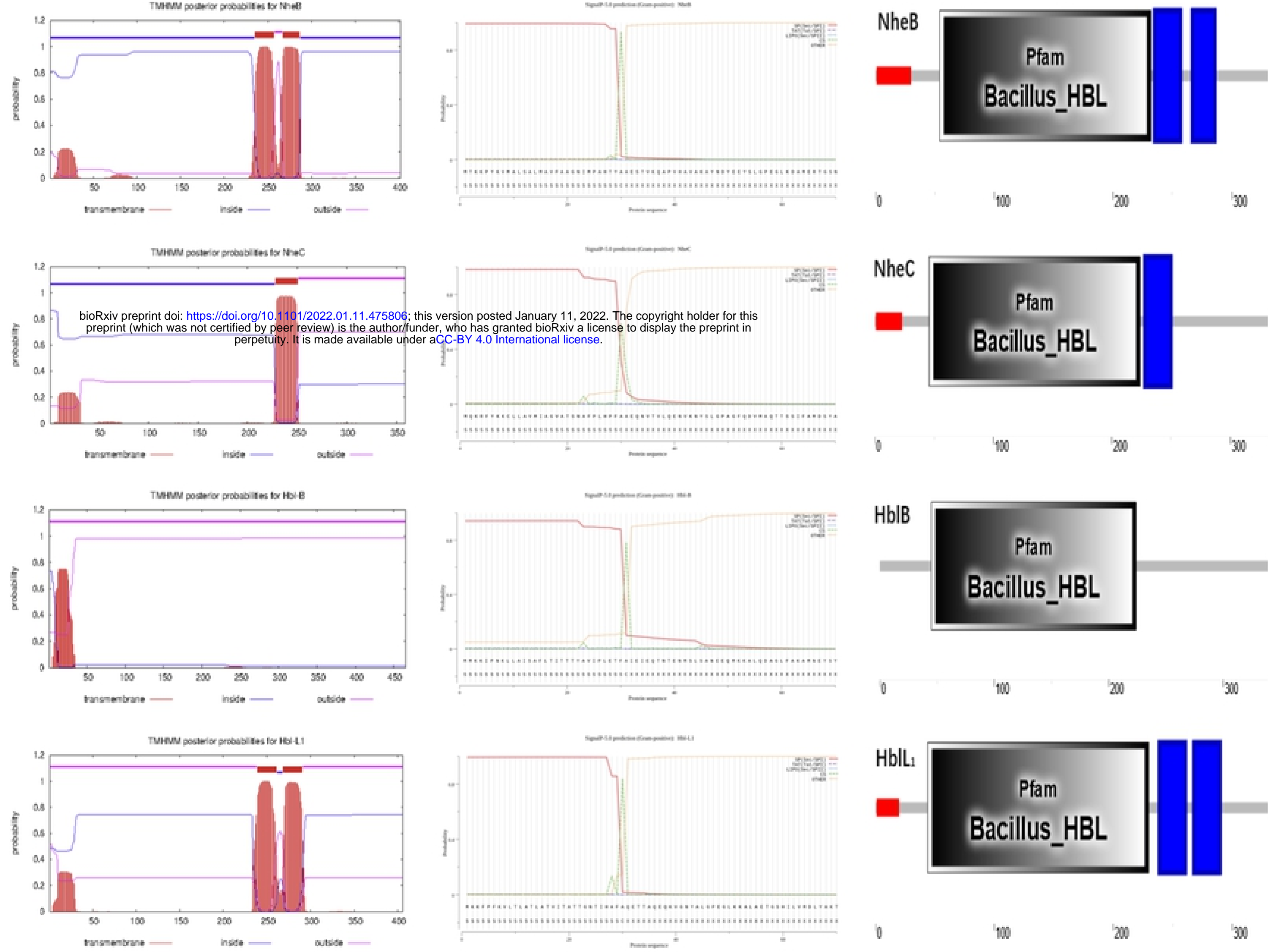

0

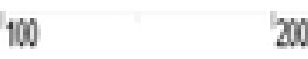

30
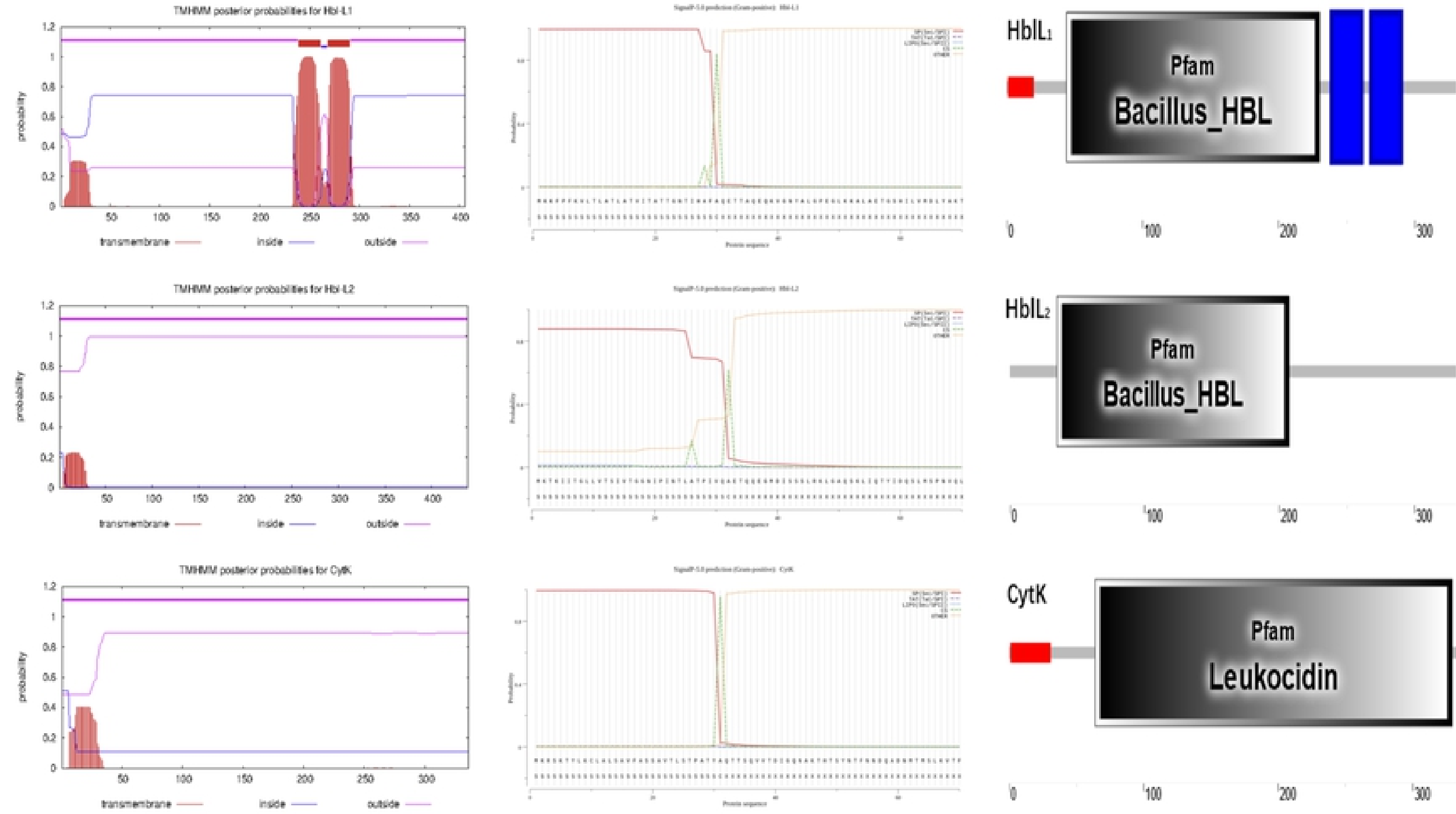

Figure 


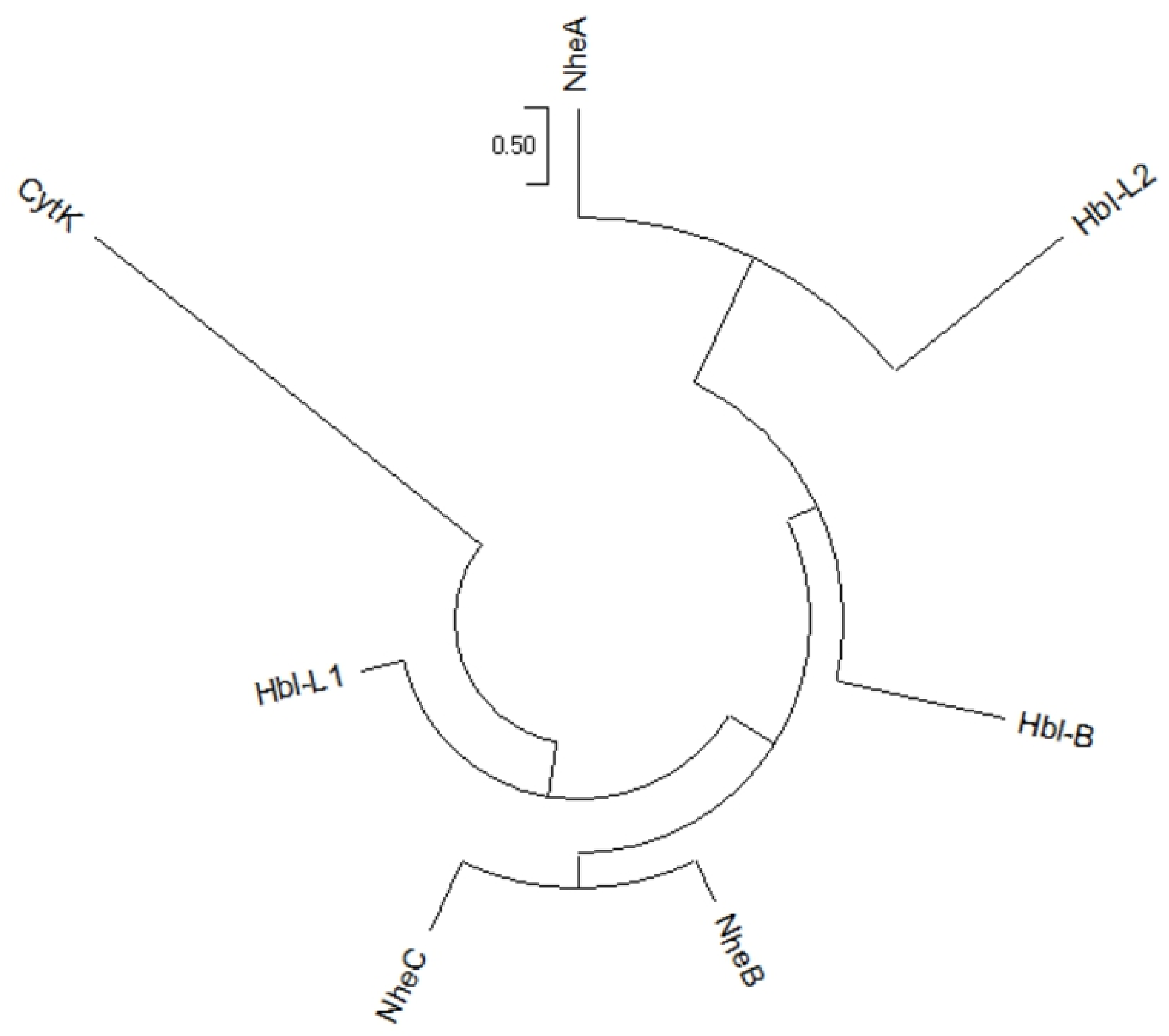

Figure 

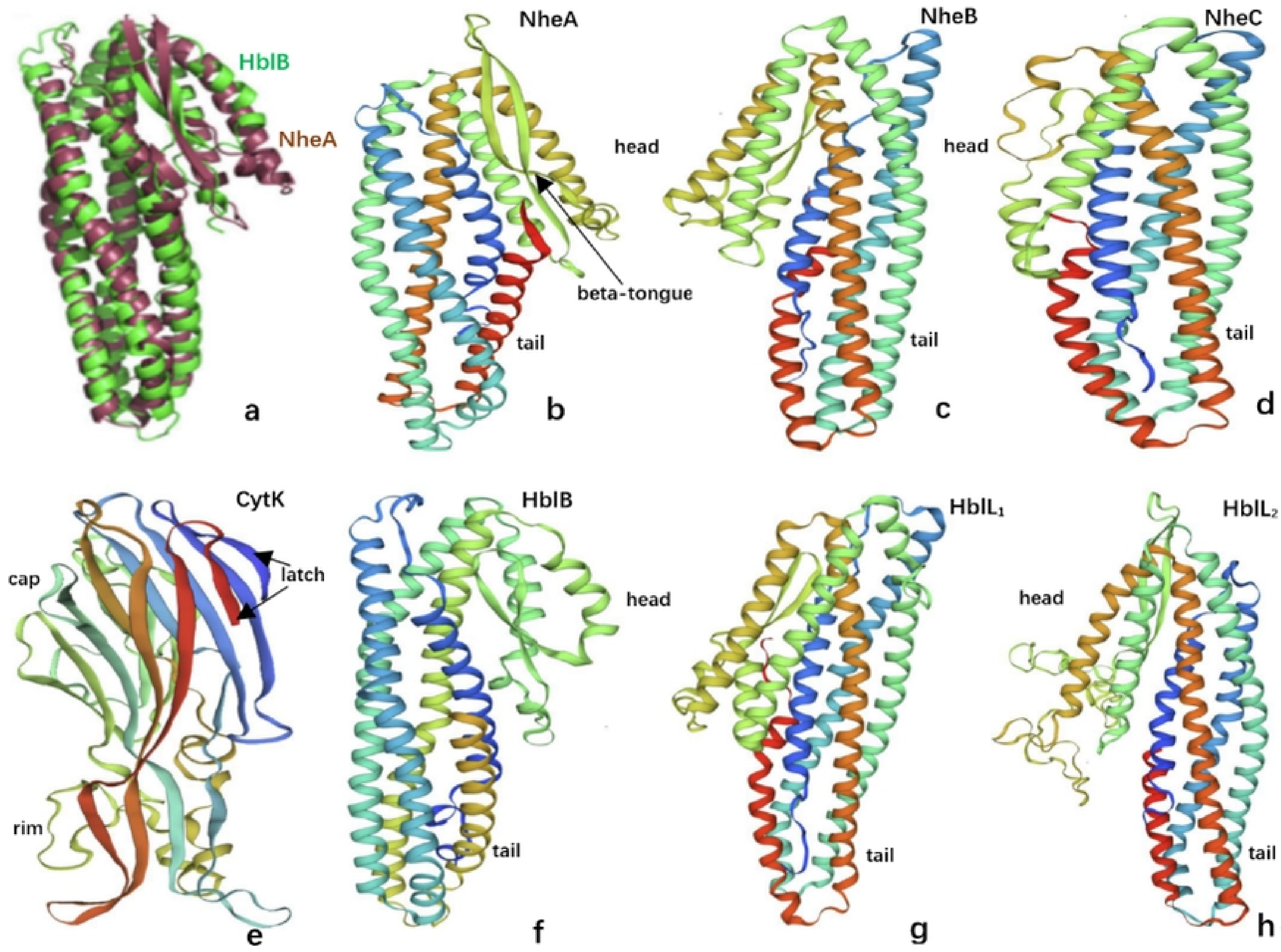

Figure 

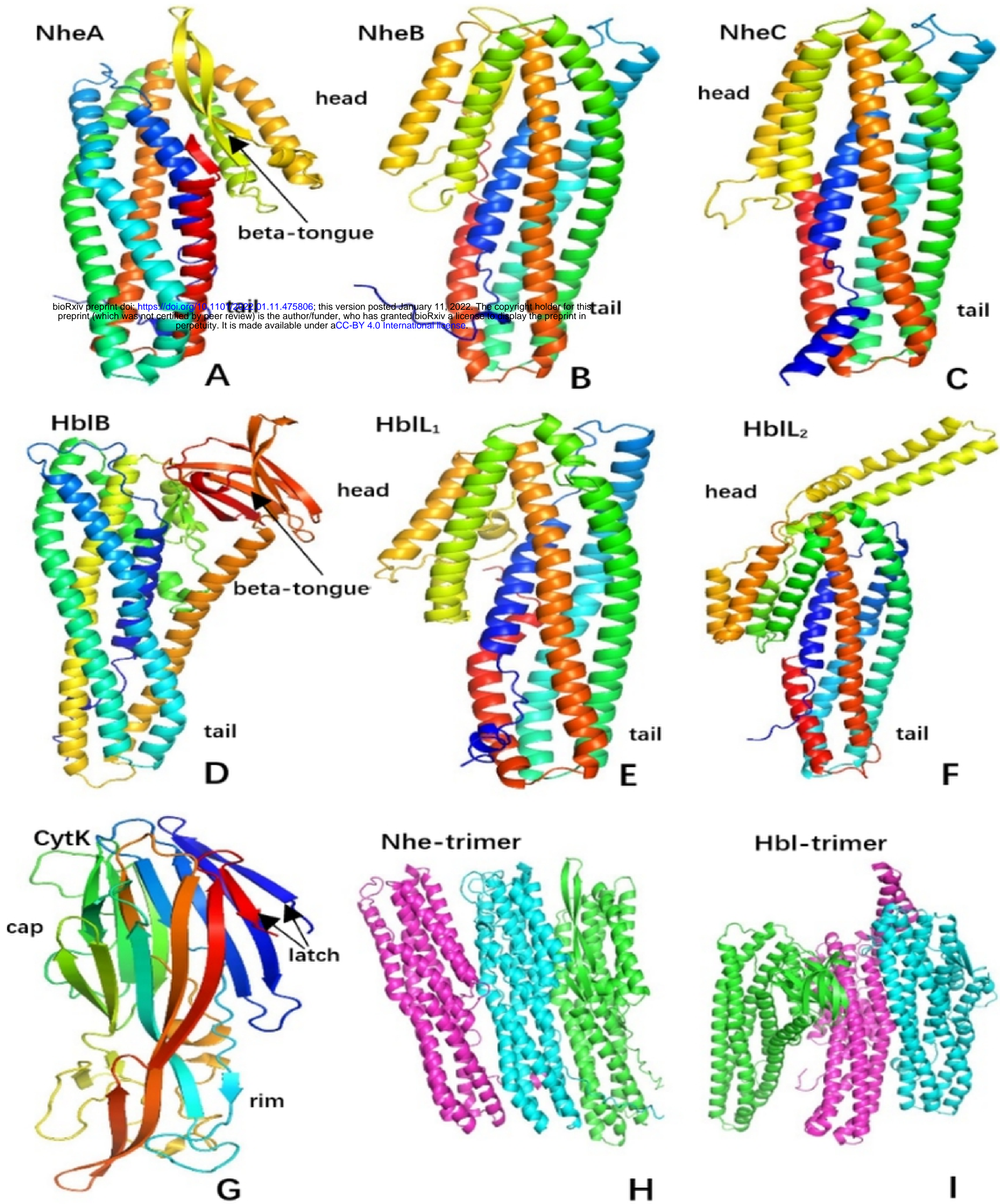

\section{Nhe-trimer}

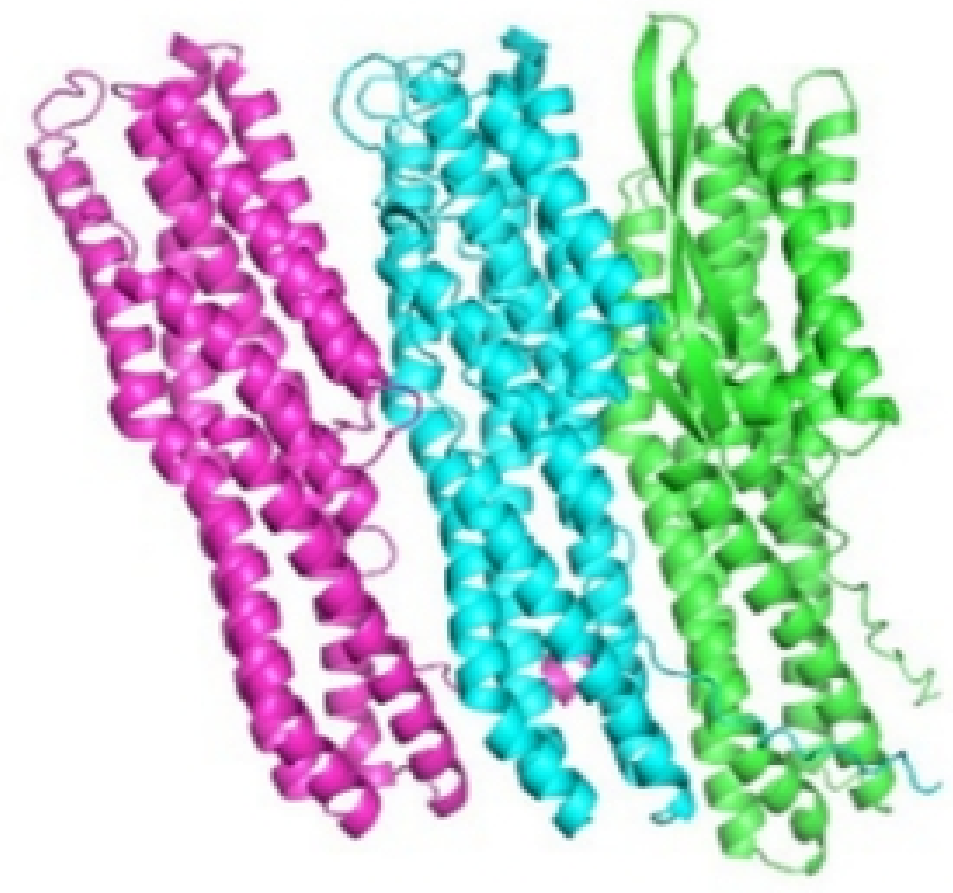

Hbl-trimer

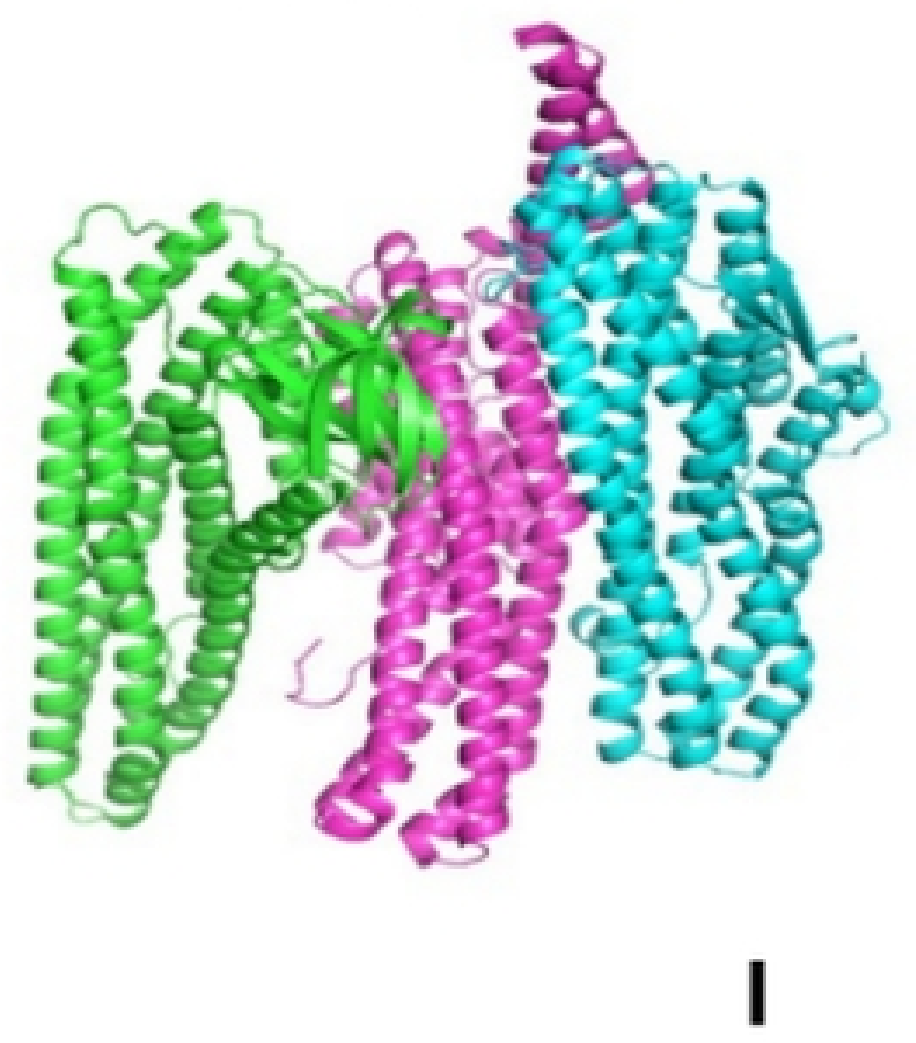

Figure

H 